\title{
Egy gyermek - két nyelv. One child, two languages. A Százszorszép Óvoda
}

\author{
Bozzayné Káli Tünde \\ Százszorszép Óvoda, Budapest
}

\begin{abstract}
A Százszorszép Óvodában 12 évvel ezelött indult a kétnyelvü nevelés (magyar és angol nyelven). A hatékonyan, sikeresen müködő pedagógiai program választ ad a kora gyermekkori nyelvoktatás, vagy ahogyan mi nevezzük, spontán nyelvelsajátitás ellenérveire, megerősíti a mellette szóló érveket. A tanulmány bemutatja a Százszorszép Óvoda nevelötestülete által kidolgozott kétnyelvüség pedagógiai módszertanát. Bemutatja a módszer hatékonyságát, bizonyságot kíván adni arra, hogy a megfelelő pedagógiai megalapozottsággal, tudatossággal felépített, az óvodai élet egészét átfogó, rendszerben müködő kétnyelvü program a 3-6 éves korú gyermek számára a teljes személyiségfejlesztés részeként kínálja az idegen nyelvet úgy, hogy mindeközben az általános fejlesztés nem sérül, sőt...
\end{abstract}

Kulcsszavak: kétnyelvüség, oktatási-nevelési program, spontán nyelvelsajátítás, angol nyelv, pedgógiai módszer

\section{Bevezetés}

2001-ben a Százszorszép Óvoda nevelötestületének nyitottsága, vállalkozó kedve az innovatív pedagógiai folyamatok megindítása felé, és a fenntartó hozzájárulása lehetőséget adott, hogy óvodánkban bevezessük, megalapozzuk az angolnyelv-tanulást, a két nyelven történő nevelést, megteremtve ennek személyi és tárgyi feltételeit úgy, hogy kialakított gyermekközpontú óvodaképünk ne sérüljön, megmaradjanak azok az értékek is, amelyeket eddig képviseltünk.

Az alábbi érveket hoztuk fel a korai idegen nyelvi fejlesztés mellett:

1. Óvodáskorban a nyelvtanulás szituációhoz kötött, utánzáson alapuló tevékenység, amelyben a gyermek kíváncsisága által motivált ismétlési késztetés a tanulási folyamat.

2. Elősegíti, erősíti a kognitív képességek fejlődését és a kreativitást.

3. A hallás utáni megértés mellett különböző észlelési területeken jut el hozzájuk az információ, tehát a keresztcsatornák fejlődésében is jelentős szerepe van.

4. A kisgyermek általános nyelvi tudatossága fejlődik, kialakul a saját és mások nyelvének létezése és változatossága iránti érzékenysége.

5. Amennyiben sikerül kisgyermekkorban felkelteni a lelkesedést a nyelvek iránt, a motiváltság megmarad, amely hozzásegíti más idegen nyelv(ek) elsajátításához.

6. Ha kisgyermekkorban találkozik egy, az övétöl eltérő kultúrával, identitástudata erősödik amellett, hogy toleráns, alapvetően nyitott attitüdü személyiséggé fejlődik.

7. Az óvodások artikulációs bázisa még nem alakult ki anyanyelvükön, még könnyen alakítható, így a kiejtésük akcentusmentes lesz.

Nem tagadjuk, hogy a szakma erősen megosztott a korai nyelvtanulást illetően. Elsősorban logopédusok, pszichológusok, óvodapedagógusok egy része tartja aggályosnak a gyermekek egészséges anyanyelvi fejlödésének nehezítése, vagy csak mint értéktelen, erre fordított, és az értékes játéktevékenységtől elvont idő miatt. Az alábbi ellenérvekkel találkoztunk az óvodai nyelvtanulással kapcsolatban: 
1. A korai idegen nyelvi tanulás megzavarja az anyanyelvi fejlődést.

2. Túl korai óvodáskorban megterhelni a gyermeket az idegen nyelvvel.

3. Elvonja az időt az értékes játéktevékenységtől.

4. A pedagógus nem megfelelő nyelvtudása, nyelvi felkészületlensége inkább kárt okoz, mert az idegen szavak rossz kiejtéssel, a mondatok esetleg helytelen grammatikával rögzülnek.

\section{Az óvodai kétnyelvű nevelési program lényege}

Az óvodánkban az „egy személy - egy nyelv”, más néven koordinált modellt alkalmazzuk, melynek lényege, hogy mindkét nyelvet külön személy képviseli. A nyelvi mintát egy-egy személy demonstrálja, így a gyermekek ösztönösen fordulnak a pedagógushoz annak saját anyanyelvén.

A nap teljes egészében (a délutáni pihenés idejét kivéve) két pedagógus foglalkozik a gyerekekkel: a magyar óvónő és az angol nevelő. Így az óvodában töltött idő teljes egészében természetes módon jut el a gyerekekhez az angol nyelv. A két pedagógus a nap folyamán mindig saját anyanyelvén beszél a gyerekekhez minden élethelyzetben. Az angol nevelök a nyelvi kifejezéseket állandóan gesztusokkal és testbeszéddel kísérik. A gyerekek a helyzetből megértik, miről van szó, tehát szituatív felfogóképességük segítségével jönnek rá a nyelvi kifejezésformák jelentésére. Az angol nevelők minden szituációhoz ugyanazt a nyelvi elemet rendelik napokon, heteken át, nonverbális úton is kísérve. Így a szó, a kifejezés természetesen, ösztönösen kötődik a szituációhoz. Az első alkalmakkor a szavaknak még csak a hangzása, dallama sejteti - különösen a hoszszabb kifejezéseknél - a mondanivalót, s csak később tisztulnak ki a szavak, mondatok, nyernek értelmet a kifejezések, ugyanúgy, mint az anyanyelv tanulási folyamatában.

\section{Kétnyelvűség a játékban}

Az utánzáson alapuló nyelvelsajátítás fő terepe a játéktevékenység, alapja az érzelmi biztonság. A játék fejleszti a gyermek mozgását, értelmi képességeit, kreativitását, az érzelmi, erkölcsi nevelés elsőszámú terepe. A játékot kísérő érzelmek közlési vágyat ébresztenek, fokozódik a gyermek beszédkedve. A beszédkedv ösztönzi a nyelvi, kommunikációs készség fejlődését. Ezért az angol nevelőnek is jó lehetőséget és alkalmat ad arra, hogy bekapcsolódva a gyermek játékába, megteremtse az idegen nyelv cselekvésbe ágyazott megértésének feltételeit.

\section{Kétnyelvűség a mozgásfejlesztésben}

A mozgás színterei: a szabad játék, a testnevelés-foglalkozás és a mindennapi, frissítő testnevelés. Hol kap ebben szerepet az angol nyelvi nevelés? Leginkább a mozgásos játékokban, melyek nagy részét a szabadban szervezzük. A mozgásos szabad játékokban is - a gyerekek igényétől függően - részt vesznek a pedagógusok, mind az angolok, mind a magyarok. A hintát hajtani még nem tudó kiscsoportosok elsők között tanulják meg a Push me! (Lökj meg!) kifejezést. A nagyobbaknak remek alkalom a mozgásfejlődés mellett az idegen nyelvi fejlődésre egy-egy közös foci vagy kosárlabdajáték az angol óvóbácsikkal. A gyermekek ezekben a játékokban számos - a mozgással, irányokkal kapcsolatos - angol kifejezést használnak a lehető legtermészetesebb módon. A mozgásos szabályjátékokat először mindig magyarul ismertetjük meg a gyerekekkel. Sok gyakorlás után adjuk át a játék irányítását az angol nevelőnek, így a szabályok megerősítésre kerülnek angol nyelven is. 
Egy gyermek - két nyelv. One child, two languages. A Százszorszép Óvoda

\section{Kétnyelvűség az irodalmi nevelésben}

Az angol nyelven közvetített irodalmi anyag kiválasztására is ugyanazok az alapelvek vonatkoznak, mint a magyar nyelvűekre, a különbség a közvetítésben van. Az angol mesékhez, versekhez elengedhetetlen a szemléltetés, a hallott szöveg képpel, mozdulattal való folyamatos kísérése, mely a kezdetben a megértést, később a felidézést segíti. Az irodalmi nevelés hatásos segítői - mindkét nyelven - a dramatizálás és a bábozás.

\section{Zenei nevelés két nyelven}

Az angol nyelvű zenei nevelés alkalmazkodik a Kodály-módszeren alapuló zenei hallás- és ritmusérzék fejlesztéshez, de betekintést enged az angolszász gyermekdalok, mondókák világába, s ezeken keresztül más népek kultúrájába. A dalanyag összeállításában segítségünkre van Forrai Katalin Ének az óvodában című könyvének angol nyelvű adaptációja, mely tartalmazza a zenei nevelés elméleti ismereteit, s hangkészletében, terjedelmében a gyermekek életkori sajátosságainak megfelelő angol nyelvü gyermekdalokat. Hatékony segítség Dietrich Helga gyermekdalgyűjteménye, mely szintén zenei kritériumait tekintve a magyar óvodai zenei nevelésen alapul, de nyelve az angol. A szervezett foglalkozásokat mindig két nyelven vezetjük, s egy-egy foglalkozás minden esetben tartalmaz magyar és angol nyelvü anyagot is.

\section{Kétnyelvűség a vizuális nevelésben}

A vizuális nevelés összetettsége magában foglalja a rajzolást, festést, mintázást, az építést, a képalakítást, a konstruálást, a kézimunkát, a műalkotásokkal való ismerkedést, a modellezést és a környezetalakítást. Miközben képi formában fejezik ki magukat a gyermekek, mintegy 'megnevezik' érzelmeiket, gondolataikat, nő önismeretük, önbizalmuk, differenciálódnak érzelmeik, fejlődik alkotóképességük. Az idegen nyelv elsajátításának egyik legjobb lehetőségét ezek a tevékenységi formák kínálják, mivel a nyelvi közvetítés a gyermekek cselekvésére irányul. Lehetőséget ad a színek, az eszközök és az ábrázolásban megjelenített formák megnevezésére. Az ábrázoló tevékenységhez és annak tartalmához kapcsolódó beszéd ösztönzésével a gyermekek nyelvi kifejezőkészsége sokoldalúan fejleszthető.

\section{Környezeti nevelés két nyelven}

A környezet megismerésére az óvodai nevelésben elsődleges fontosságot tulajdonítunk a tapasztaláson alapuló ismeretszerzésnek. Mivel mindegyik foglalkozásunkat két nyelven vezetjük, minden téma alapszókincse angolul is beépül az ismeretszerzés folyamatába, újabb csatornát nyitva az ismeretek, tapasztalatok megszilárdulásának, gyakorlati alkalmazásának.

\section{A kétnyelvű nevelés hatása a gyermekek komplexszemélyiség-fejlődésére}

Mivel ehhez hasonló kétnyelvű nevelési program alapján Magyarországon még nem müködött óvoda, a program kidolgozása, pontosítása, a gyakorlati megvalósítás lehetőségeinek kidolgozása az elmélet alapján az első években párhuzamosan folyt az első kétnyelvű csoport beindulásával. A nevelés magas színvonalon való művelése, a 
gyermekek egészséges, harmonikus testi, lelki fejlődése megkívánja, hogy folyamatosan mérjük az eredményeket a fejlesztés minden területén. Az eredmények kimutatására összehasonlító elemzést végeztem. Az összehasonlított két csoport: a kétnyelvű program bevezetésekor az óvodánkban még egynyelvűként működő nagycsoport (kontrollcsoport) és a kétnyelvü csoport.

A vizsgálat tárgya: a tanulási képességeket meghatározó pszichikus funkciók vizsgálata:

- mozgáskoordináció,

- vizuális percepció,

- auditív percepció,

- keresztcsatornák együttmüködése,

- rövid idejű vizuális és verbális memória,

- szándékos figyelem.

\section{A mérést szolgáló eljárások:}

- Porkolábné dr. Balogh Katalin által kifejlesztett fejlettségmérő lapok alapján történő folyamatos megfigyelés és feljegyzés.

- Nagycsoportban iskolaérettségi vizsgálat, mely a következő területeket érinti: mozgás, testséma, téri tájékozódás, finommotorika, vizuális, auditív percepció, keresztcsatornák, rövid távú vizuális és verbális memória, figyelem, gondolkodás, nyelvi és szociális fejlettség (lásd 1. ábra).

- Adatgyűjtés: a szülők iskolai végzettsége és foglalkozása a rendelkezésre álló dokumentumok alapján. Beszélgetés a szülőkkel, családlátogatások. Mindezen információkból a gyermekek szociokulturális hátterét igyekeztem felderíteni.

A két vizsgált csoport szociális háttere: A két csoport életkorát tekintve homogén, a gyermekek szociális hátterét tekintve némi eltérés tapasztalható a kétnyelvű csoport gyermekeinek javára, de mindkét csoportra többségében jellemző a segítő, támogató szülői háttér.

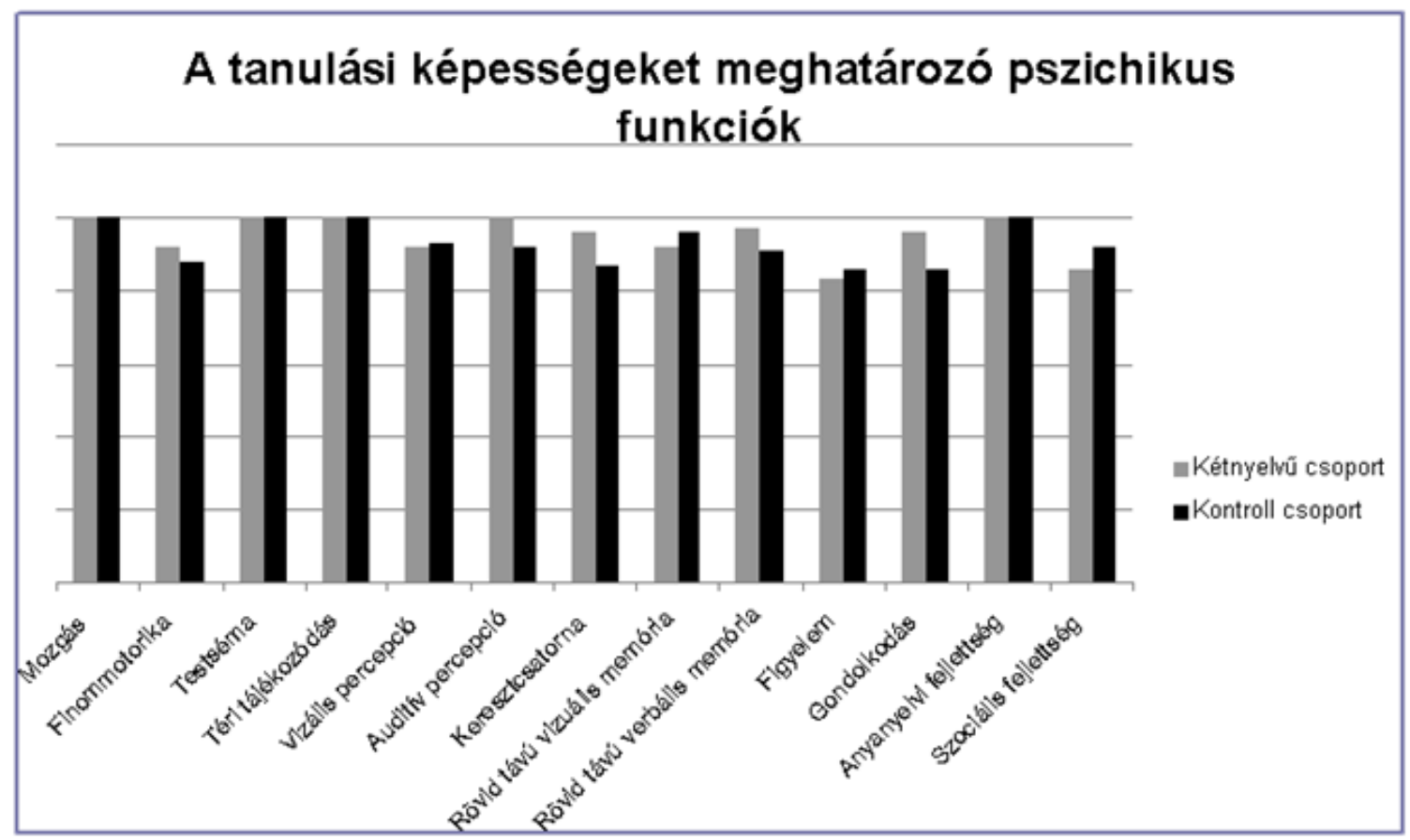

1. ábra: A tanulási képességeket meghatározó pszichikus funkciók 


\section{Eredmények}

Vizsgálatom célja az volt, hogy tisztázzam, van-e olyan területe az óvodai nevelésnek, melyben a kétnyelvü környezet zavart, lemaradást okozhat a fejlödésben, illetve van-e olyan terület, melyet erősít. A mozgás, testséma, téri tájékozódás és anyanyelvi fejlettség területeken mindkét csoport minden tagja elérte az iskolaérettség szintjét.

Az anyanyelvi nevelés mindig erősen hangsúlyos szerepet kapott óvodánk nevelési programjában. Bebizonyosodott, hogy az időközben belépő kétnyelvű program nem hátráltatja ezt a folyamatot, az angol nyelv elsajátítása mellett az anyanyelv ápolására, fejlesztésére is kellő idő és lehetőség áll a magyar óvodapedagógusok rendelkezésére. Mivel a gyermekek anyanyelvi fejlődését kiemelt feladatként kezeljük, folyamatosan mérjük, vizsgáljuk.

Érdekes eredménye a felmérésnek, hogy a kétnyelvű csoportba járó gyermekek auditív percepciója fejlettebb, annak ellenére, hogy a figyelem fejlettsége gyengébb eredményt mutat a kétnyelvű csoportnál. (A vizuális és auditív percepció nagyban öszszefügg a figyelem fejlettségével.) Hétköznapi megfigyeléseinket erősíti ez az eredmény, miszerint a két nyelv jelenléte az egész nap folyamán segíti a hallási észlelést, a hangzási analízis-szintézist.

Gyengébb eredményt mutat a kétnyelvü csoport a figyelem területén. Ez arra hívja fel a figyelmünket, hogy további vizsgálódást folytassunk, mi okozhatja a gyerekek koncentrációs problémáit. Meg kell vizsgálni, hogy a gyermekeket egy időben érő külső ingerek nem terhelik-e túl az idegrendszerüket.

Szintén gyengébb eredményt mutat a szociális fejlettség a kétnyelvü csoportban. Ennek oka lehet a szülők túlterheltsége. A hozzánk járó gyermekek szülei döntő többségében magasan kvalifikált, sokan vezető beosztású fiatalemberek. Munkájukban való leterheltségük miatt kevesebb időt tudnak gyermekeikkel tölteni. Sokan küzdenek közülük gyermeknevelési problémákkal, vagy egyszerüen csak tájékozatlanok, nem tudják, mit várhatnak el óvodáskorú gyermeküktől. Ebből adódó feladatunk a szülők folyamatos segítése, az óvoda-család hatékony együttmüködésének fejlesztése, beszélgetési lehetőségek megteremtése, ahol választ kaphatnak kérdéseikre, elmondhatják gondolataikat, megoszthatják problémáikat a pedagógusokkal és más szülőkkel.

Magasabb eredmény mutatkozik a kétnyelvü csoportban a keresztcsatornák és a gondolkodás fejlettségében. A mindennapok tapasztalata és ez a felmérés is igazolni látszik azt a feltevést, hogy egy második nyelvvel való korai ismerkedés egy újabb csatornát nyit az ismeretek befogadására, és a nyelv által kreatívabb lesz a gyermekek gondolkodása.

\section{Összegzés}

Összegezve elmondhatjuk, hogy felkészült, tudatos, tervezett és szervezett nevelömunkával mind az egynyelvü, mind a kétnyelvü óvodai környezet lehetőséget nyújt az óvodapedagógusnak arra, hogy a gyermekek egyéni fejlődési ütemét követve képességeiket kibontakoztassa, s az angol nyelv megjelenése (természetesen a gyermekek életkori sajátosságainak szem előtt tartásával) nem akadályozza, inkább segíti az óvodapedagógiai törekvések megvalósítását. 


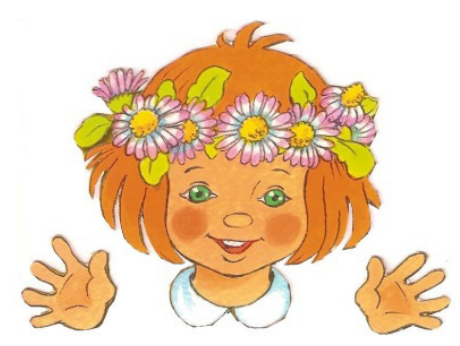

2. kép: Az óvoda logója

\section{Felhasznált irodalom}

Forrai Katalin (1994): Ének az óvodában. Editio Musica, Budapest.

Porkolábné Balogh Katalin (2004): Komplex prevenciós óvodai program. Trefort Kiadó, Budapest. 